\title{
Wincenty Pol i ks. Karol Antoniewicz - wspólnota ducha i twórczości
}

\author{
Więc żyj w świadectwie i świadectwo dawaj, \\ I pod gwiazdami jak w swym domu stawaj, \\ Znaj gwiaździstego nieba starą kartę \\ I stróża - gwiazdę i stróża - anioła, \\ Bo życie nasze o tyle tu warte, \\ O ile z niebem człek je związać zdoła ${ }^{1}$.
}

\incenty Pol (ur. 20. 04. 1807) i ks. Karol Antoniewicz SJ (ur. 6.11.1807) ks. Antoniewicza i innych polskich Ormian za ich pracę dla ojczyzny. Do nich odnosił słowa Pisma św. mówiące o tym, że: „,cichy posiądzie ziemię”, gdyż to właśnie polski Ormianin wszędzie tam, gdzie jest, „wprowadza język, obyczaj polski, katolickie przekonania i postępowe gospodarstwo”2. Obu poetów łączy miłość ojczyzny i wrażliwość na piękno ojczystej przyrody oraz przekonanie, że u źródeł tożsamości narodu leży wspólnota wiary i tradycja języka. Po bliższym przyjrzeniu się ich biografii i twórczości, zauważyć można wiele podobieństw zarówno w faktach biograficznych, jak i w stylu i podejmowanych tematach.

\footnotetext{
* S. DR Bożena LeszczyŃsKa - Uniwersytecki Szpital Dziecięcy w Krakowie; e-mail: b.leszczynska@op.pl.

${ }^{1}$ W. Pol, Zegar niebieski doroczny, w: tenże, Rok myśliwca (z rysunkami Juliusza Kossaka), Poznań 1870, s. 8.

${ }^{2}$ Zob. W. Pol do ks. Aleksego Prusinowskiego, Przemyśl, październik 1861, list nr 338, w: Listy zziemi naszej. Korespondencja Wincentego Pola z lat 1826-1874, oprac. i wstęp Z. Sudolski, Warszawa 2004, s. 377.
} 


\section{Środowisko rodzinne}

Tym, czym była miejscowość Mostki dla Wincentego Pola, tym dla Karola Antoniewicza była Skwarzawa. Obie wsie są położone blisko Lwowa. Mostki należące do wujostwa Marii i Józefa Ziętkiewiczów uważał Pol za miejsce rodzinne. Tam po śmierci ojca spędzał sporo czasu, tam poznał piękno wiejskiej przyrody, pokochał lud i jego obyczaje. To w Mostkach zrodziło się jasne i pogodne spojrzenie na świat, zachowane nawet w najboleśniejszych chwilach życia, które kierowało umysł poety do opisywania cudów przyrody i odczucia piękna naszej ziemi ${ }^{3}$. Karol Antoniewicz zaś powracał zawsze we wspomnieniach do Skwarzawy, z uroczym dworkiem, modrzewiową aleją i ogrodem: „O wiosko, tak droga sercu memu, twój obraz wyciśnięty na duszy nigdy w pamięci mojej nie zaginie!"

Cała rodzina Polów była bardzo muzykalna. Ojciec, wykształcony i towarzyski, podobnie jak i starsi bracia Wincentego, grał na skrzypcach i altówce, matka zaś i siostry na fortepianie; on zaś sam próbował gry na wiolonczeli. Częstymi gośćmi byli w ich domu najwybitniejsi wówczas przedstawiciele świata muzycznego, m.in. Franz Xaver - syn Wolfganga Amadeusa Mozarta ${ }^{5}$, czy Karol Lipiński ${ }^{6}$. Znajomość muzyki pomogła poecie nadać harmonijną formę tworzonym przez siebie utworom, o czym pisał m.in. Maurycy Mann w studium biograficzno-krytycznym poświęconym Polowi:

Ta nieskazitelna rytmiczność i gładkość wiersza, który nigdy nie kulał, nigdy nie był chropowatym, ta zdolność mówienia rytmem, improwizowania dłuższych nawet utworów, mają swoją przyczynę przede wszystkim w tym muzykalnym otoczeniu, śród którego wzrastał przyszły śpiewak Pieśni o ziemi naszej ${ }^{7}$.

Karol Antoniewicz również kochał muzykę i wiele godzin spędzał przy ulubionym fortepianie, wykonując najtrudniejsze utwory muzyczne i układając muzykę do własnych wierszy. Do dziś zachowały się dwa skomponowane przez niego walce pt. Wspomnienia Mikuliczyna ${ }^{8}$, które dedykował swej siostrze Albinie.

${ }^{3}$ F. Morzycka, Wincenty Pol: życiorys, Warszawa 1899, s. 8.

${ }^{4} \mathrm{~K}$. Antoniewicz, Dwa listy o Zofji Antoniewiczowej, Freywaldau, 26 wrzesień 1848, „Pokłosie. Zbieranka literacka na rzecz sierot", Poznań 1862, r. VI, list I, s. 16.

${ }^{5}$ Franz Xaver Wolfgang Mozart w roku 1813 zamieszkał we Lwowie (stąd przydomek „Mozart Lwowski"). Mieszkał tam przez 25 lat i pracowal jako nauczyciel gry na fortepianie.

${ }^{6}$ M. Mann, Wincenty Pol - studium biograficzno-krytyczne, t. 1, Kraków 1904, s. 20-21.

7 Tamże, s. 21.

${ }^{8}$ Archiwum Prowincji Polski Południowej Towarzystwa Jezusowego w Krakowie; rękopis, dalej: ATJKr rkps, 1012 - I, Pisma i notatki ks. Iwona Czeżowskiego o życiu ks. Karola Antoniewicza, które posłużyly ks. Badeniemu za materiał do napisania dzieła „Ksiądz Karol Antoniewicz”, karta 
Matka W. Pola - łagodna, skromna i inteligentna, rozmiłowana była w kwiatach i poetyckiej twórczości Franciszka Karpińskiego i Ignacego Krasickiego. Zapewne miało to duży wpływ na łatwość wierszowania i rytmiczność poezji jej syna ${ }^{9}$. Wychowanie Wincentego było jej dziełem, stąd zawsze z rzewnością wspominał on swe dziecięce lata, "gdy na matki igrał łonie, w malowanych snach"10. Podobnie Karol w swym młodzieńczym wierszu przywoływał czas, gdy „zachwycone bezpiecznym istnieniem dziecko, bez bólu i trosk, spoczywało w ramionach matki"11. Podkreślając zaś jej powołanie i godność, przekonywał: "Gdzie nie ma matki, tam nie ma rodziny i tam nie ma narodu!" ${ }^{2}$. Liczący kilkanaście stron rękopis - wzruszające wspomnienie o tej najbliższej sercu osobie, odnalezione właśnie w zbiorach Pola, stanowi jeszcze jeden dowód tego, że w życiu obu poetów spełniała ona rolę wyjątkową ${ }^{13}$.

Obaj poeci w wieku 16 lat zmierzyli się z doświadczeniem żałoby. Ojciec Karola - lwowski adwokat - zmarł 23 marca 1823 roku, zaś dwa dni później stracił ojca - radcę sądu krajowego we Lwowie - Wincenty. Było to dla młodzieńców bardzo trudne przeżycie, do którego powracali jeszcze wiele lat później. Autor Pieśni o ziemi naszej pisał:

Nie liczyłem jeszcze siedemnastu lat, gdy utraciłem najlepszego z ojców. [...] Właśnie wtenczas ostatnie dni pogodnego kwietnia ubarwiały łąki, rozwijały sady i krasiły bory. Spojrzałem na naturę i pierwszy raz zacząłem myśleć: nad sobą, nad światem i jego pięknością, nad człowiekiem i jego przeznaczeniem. Tłumy wrażeń wewnątrz cisnęły się do mej duszy, która dopiero działać zaczęła, lecz czucie i rozum niewykształcony nie mogły ich dokładnie rozeznać ani uporządkować! [...]. Smutek, w którym z przyczyny śmierci kochanego ojca pogrążony byłem, kazał mi szukać samotności ${ }^{14}$.

Opis tych bolesnych chwil zanotował w swym pamiętniku również Karol, który nad grobem ojca zaczął rozumieć to, co daje życie i to, co zabiera śmierć.

60; walce (litografia 1844, Lwów, Biblioteka Ossolineum). Zachował się też Polonaise pour le Piano Forte: composée et dediée a Madame Regina Froberg, Lwów 1835.

${ }^{9}$ M. Mann, Wincenty Pol - studium biograficzno-krytyczne, t. 1, s. 18.

${ }^{10}$ Por. tamże, cyt. z wiersza W. Pola pt. Gwiazdka, s. 17.

${ }_{11}$ ATJKr, rkps 1012 - I, Pisma i notatki ks. Iwona Czeżowskiego o życiu ks. Karola Antoniewicza..., karta 27.

${ }_{12} \mathrm{~K}$. Antoniewicz, O powołaniu kobiety, list IV, Gräfenberg, wrzesień 1849, w: ATJKr, rkps 932 - C, t. I, Różne pisma i druki ks. Karola Antoniewicza, karta 26.

${ }_{13}$ Tekst ten został opublikowany w: K. Antoniewicz, Wspomnienia życia zakonnego, „Dzwonek. Pismo młodemu wiekowi poświęcone”, Lwów 1850, s. 42-48. Rękopis w zbiorach W. Pola przepisany jest w dużej części przez żonę Kornelię oraz prawdopodobnie przez córkę; zob. K. Antoniewicz, Wspomnienie życia zakonnego matki, w: Sylwetki matek kapłanów, red. Z. Walkiewicz, PoznańWarszawa 1981, przypis, s. 9.

${ }^{14}$ W. Pol, Pamiętniki, oprac. K. Lewicki, Kraków 1906, s. 29-30. 
Podobnie jak Wincenty szukał ukojenia bólu i tęsknoty w pięknie przyrody, przekonując się, że wielkim szczęściem jest w widokach natury i w prostych wrażeniach życia odnaleźć skarb na czas posuchy serca i nieurodzaju ducha ${ }^{15}$ :

Jeden dzień odmienił mnie zupełnie, był to dzień śmierci ojca mego, od dnia tego przestałem się śmiać, spoważniałem, osmutniałem bardzo i począłem myśleć: [...] zrozumiałem wszystko, życie i śmierć i to, co życie dać może i to, co śmierć bierze. Płakać nie mogłem, ale przestałem sypiać po nocach, a we dnie szukałem samotności ${ }^{16}$.

Po śmierci ojca Pol rozpoczął naukę w gimnazjum jezuitów w Tarnopolu. Szkoła ta była dla niego ostatecznym etapem na drodze jego wychowania religijnego. Zarówno w pismach, jak i w życiu ten religijny, mocno ugruntowany $\mathrm{w}$ wierze pogląd, już się nie zmienił ${ }^{17}$.

W roku 1827 obaj poeci ukończyli studia we Lwowie: Wincenty filozofię, a Karol studia prawnicze. Oczytani w dziełach pisarzy niemieckich i doskonale władający językiem niemieckim, szybko nawiązali serdeczne stosunki ze znakomitościami stolicy oraz ze światem uczonych i twórcami kultury we Wiedniu. W 1831 roku obaj zaś wzięli udział w powstaniu listopadowym - Pol jako podchorąży 10 Pułku Ułanów Litewskich, Antoniewicz służąc w oddziale gen. Józefa Dwernickiego. Po powrocie z powstania Wincenty ożenił się z Kornelią Olszewską. „Żona moja dała mi spokój i szczęście! Od czasu ożenienia ukołysały się losy moje nieco"18 - pisał. Karol zaś, po krótkim pobycie na emigracji, w roku 1832 zawarł ślub z Zofią Nikorowiczówną. Mówił o niej, że jest „aniołem” i wspominał, że w radości i cierpieniu zawsze była dla niego "gwiazdą zbawienia i kotwicą nadziei”"19, której mocno uchwyciły się jego dłonie.

Małżeńskie szczęście obu poetów nie trwało jednak długo; już na początku przerywa je wielkie cierpienie. W roku 1838 Polowi umierają pierwsze dzieci - bliźnięta. Córeczka przyszła na świat bez oznak życia, syn Janusz żył bardzo krótko. Antoniewiczowi zaś, któremu śmierć zabiera całe potomstwo, właśnie na wiosnę tego roku umiera piąte, ostatnie dziecko.

Osobisty dramat nie zamyka ich serc na cierpienia innych ludzi, lecz jeszcze głębiej je uwrażliwia. Pol wówczas bardziej zbliża się do ludu i widząc jego biedę, szuka środków, by pomóc, buduje biedakom chaty i zakłada przy dworze duży

${ }^{15}$ K. Antoniewicz, Wyjątek z pamiętników. Rok 1823, „Dzwonek. Pismo młodemu wiekowi poświęcone", Lwów 1851, t. IV, s. 31.

16 Tamże, s. 28.

${ }_{17}$ M. Mann, Wincenty Pol - studium biograficzno-krytyczne, t. I, s. 49.

${ }_{18}$ W albumie Ksawerego Preka w roku 1840, cyt. za: M. Mann, Wincenty Pol - studium biograficzno-krytyczne, t. I, s. 323.

${ }_{19}$ K. Antoniewicz, Dwa listy o Zofji Antoniewiczowej, s. 10. 
ogród, gdzie mogą pracować2 ${ }^{20}$. Pisze: „Nigdy w mym życiu nie byłem pożyteczniej i realniej zajęty i nie w osobistych widokach, ale w tym przekonaniu, że dobrą wolą i światłem trzeba przodkować ludowi, że trzeba wyrównać krzywdę przeszłych czasów i wymiarem sprawiedliwości wybłagać dla siebie u Boga ukojenie duszy”21.

Miejscem zawsze otwartym i gościnnym był także dwór Antoniewicza. Młodzi małżonkowie zorganizowali u siebie nawet szkółkę dla wiejskich dzieci i skromny szpitalik, gdzie opiekowali się chorymi biedakami.

W roku 1839 Polowi urodzi się syn Wincenty, a Karolowi w tym samym roku umiera żona i wstępuje on do zakonu jezuitów, by przez dziewięć lat służyć tam Bogu i ludziom w trudnych realiach zniewolonej ojczyzny. Jako najdroższą pamiątkę po Zofii zachowuje własnoręcznie przez nią napisany „Porządek dzienny” zawierający rady, jak ma przeżywać codziennośćč ${ }^{22}$. „Miłość do Zofii dochował niezwiędłą - pisał Sadok Barącz - nie wspominał o niej inaczej, jak tylko z zachwyceniem i uwielbieniem" ${ }^{23}$. Służąc umierającym z powodu cholery ludziom, umiera 14 listopada 1852 roku w Obrze, w wieku 45 lat, dzieląc do końca okrutny los ofiar szalejącej epidemii.

Trzy lata później, w 1855 r. na cholerę zachoruje żona Pola i po jej śmierci zostaje on sam z kilkorgiem dzieci. Owdowiały, wstrząśnięty i „nieuleczalnie zbolały" poeta, w apostroficznych Trenach, w swym pierwszym i jedynym wierszu poświęconym Kornelii, nazywa ją opiekuńczym duchem „natchnienia i lutni”, leczącym świat samym swoim istnieniem. Zaś ślubny pierścień składa w darze Matce Bożej Częstochowskiej:

Królowo Nieba! Pani dobrej wieści!
Matko miłości i Matko boleści!
Oto się ciskam do stóp Twoich w prochu,
Przyjm moją żałość i mą miłość w szlochu [...].
Oboje składam Tobie jako wieniec
To polskie pióro i ślubny pierścieniec ${ }^{24}$.

Taki sam dar po śmierci żony złożył Maryi Karol Antoniewicz. Ślubny pierścień, wprawiony w złotą koronę okalającą skroń niewielkiej figurki Madonny z nowicjackiej kaplicy w Starej Wsi, był potwierdzeniem i znakiem zewnętrz-

${ }^{20}$ M. Mann, Wincenty Pol - studium biograficzno-krytyczne, t. 1, s. 324.

${ }^{21}$ Tamże.

${ }^{22}$ ATJKr, rkps 1012 - I, Pisma i notatki ks. Iwona Czeżowskiego o życiu ks. Karola Antoniewicza..., karta 71.

${ }^{23}$ S. Barącz, Antoniewicz de Bołoz Karol, w: tenże, Żywoty sławnych Ormian, Lwów 1856, s. 19.

${ }^{24}$ W. Pol, Do Najśw. Panny Maryi Częstochowskiej, cyt. za: Z. Chojnowski, Osobowość religijna Wincentego Pola, w: „Ponad hafem wicher wieje”... Studia o Wincentym Polu, red. N. Kasparek, A. Korytko, Olsztyn 2011, s. 128. 
nym podjętych przez niego ślubów zakonnych: „O jedną łaskę prosił [Karol], aby mógł przechowywany po Zosi pierścień swój ślubny Najświętszej Pannie, jako zakład nowego dozgonnego zaślubienia swego ofiarować"25, zanotował jeden $\mathrm{z}$ biografów.

Pola i Antoniewicza łączy więc przede wszystkim głęboka wiara w Boga, miłość do Matki Bożej, wrażliwość na piękno ojczystej przyrody, troska o los zniewolonej przez zaborców ojczyzny oraz prostota i śpiewność poezji. Ich przeniknięta patriotycznym duchem twórczość, nie pozwalała tracić nadziei tym, którzy z utęsknieniem wyczekiwali zmartwychwstania Polski ${ }^{26}$.

\section{Piękno ojczystej ziemi}

Ku jakiemukolwiek przedmiotowi Pol kierował myśl, wszystko odnosił do Boskiego początku i działania. Wytrwale nawoływał do wierności Bogu i Jego Kościołowi, do szacunku wobec tradycji, obyczajów i tej ziemi, z którą wszystko wiązał ${ }^{27}$, pisał Lucjan Siemieński.

Poezje Pola są odbiciem stanu duszy poety. W obrazy natury wlewa on wiele wrażeń i myśli, które wiążą się w całość, uosabiając pojęcia i przedmioty, ważne w życiu narodu i jego tradycji. Przemawiają więc często w jego utworach upersonifikowane rzeki i góry, jeziora i morza, łany zbóż, puszcze i stepy, mogiły, wreszcie ptaki i domowa strzecha, kościółek i cerkiew ${ }^{28}$. Przyroda często stanowi tło dla poetyckiego przekazu ludowych podań. Zachwyt nad życiodajną siłą, znajdującą się w ukształtowanym przez górską naturę cechach osobowościowych mieszkańców, prowadził poetę do głębokich refleksji. W swych utworach, zarówno w przyrodoznawczo-literackim reportażu: Obrazy z natury, jak i w poetyckich Obrazach $z$ podróży, poprzez efekty kolorystyczne i emocjonalne impresje, Pol stworzył swoistą mistykę gór, rozbudzając statyczną panoramę metafizyką wewnętrznego życia natur $y^{29}$. O mistyce gór można także mówić, interpretując utwory Karola Antoniewicza. Romantyczny wędrowiec na szczycie gór, ponad chmurami, zdobywał "nowe czucie, śmielsze życie”"30, inne od tego,

${ }_{25}$ Zob. ATJKr, rkps 1012 - I, Pisma i notatki ks. Iwona Czeżowskiego o życiu ks. Karola Antoniewicza..., karta 117.

${ }^{26}$ P. Czartoryski-Sziler, Wielcy zapomniani. Wincenty Pol - twórca „Mohorta”, „Nasz Dziennik”, http://www.lwow.com.pl/naszdziennik/pol.html [25.05.2017].

${ }^{27}$ L. Siemieński, Wincenty Pol i jego poetyczne utwory, Kraków 1873, s. 50.

${ }^{28}$ M. Wiśniowiecki (oprac.), przedm. do: Dzieła poetyckie Wincentego Pola, t. III, Stanisławów 1903, s. 14.

${ }^{29}$ Por. M. Łoboz, Piękna nasza Polska cała... Krajobrazy Wincentego Pola, Wrocław 2007, s. $138-142$.

${ }^{30}$ K. Antoniewicz, Góry, w: Poezje o. Karola Antoniewicza TJ, wyd. J. Badeni TJ, t. II, Poezje różne, Kraków 1895, s. 175. 
które pozostało w dolinie codzienności, a natura współcierpiała z człowiekiem przeżywającym ból istnienia:

\author{
Więc i natura ma także westchnienie, \\ I naszą duszą jej dusza oddycha? \\ Gdy źródło uczuć już w sercu wysycha, \\ Ona łzy suszy, podziela cierpienie ${ }^{31}$.
}

„Nie poeta, kto nie rozumie głosów naturę - twierdził zaś Pol - i dodawał, że: „Dla profana każde drzewo szumi jednako, strumień dzwoni na tę samą nutę; dla poety każdy listek powinien mieć swoją odrębną mowę. Przez zrozumienie natury przechodzimy do poznania Boga"s2. To odkrycie związane jest $z$ bolesnym doświadczeniem poety, jakim w ostatnich latach życia była utrata wzroku. Ale właśnie wtedy, gdy już nie widział, dotykał innego, duchowego sposobu poznania i widzenia. Nieraz zdumiewał przyjaciół tym, że nazwy wszystkich drzew rozpoznawał tylko po szumie liści i po zapachu.

Pol podróżując po Tatrach i Pieninach, obserwował też kulturę tamtejszych mieszkańców, odwiedził Bieszczady i Beskidy. W Karpatach Wschodnich zafascynował się huculszczyzną, regionem położonym na pograniczu ukraińsko-rumuńskich gór, otoczonych rzekami Prut i Czeremosz. W trakcie wielokrotnych pobytów w tym regionie mógł bardzo dokładnie poznać nie tylko rzeźbę terenu i systemu wodnego, lecz także życie Hucułów. Jego korespondencja obfituje więc w szczegóły dotyczące trybu podróżowania i sposobu spędzania czasu w tych pięknych, ale i niebezpiecznych górach. Nie brak w nich również opowieści o rozbójniku Doboszu i jego drużynie, których nie skąpili góralscy przewodnicy. Etnograficzne poglądy autora Pieśni o ziemi naszej istotnie zaważyły na badaniach huculskiej kultury w XIX wieku ${ }^{33}$. Już w roku 1842 w „Rozmaitościach” ukazała się jego rozprawa Rzut oka na pólnocne stoki Karpat, w poznańskim "Tygodniku Literackim” Obrazy z życia i podróży, a w roku 1845 Wspomnienia $z$ podróży.

Znawcą tych regionów był też Karol Antoniewicz, którego zaliczano do grona największych miłośników gór w naszym piśmiennictwie epoki romantyzmu ${ }^{34}$. Dziełem poety są m.in. Wspomnienia z wędrówki przez Góry Olbrzymie. Riesengebirge w roku 1837 z wyprawy w Sudety. Do poznania zaś Karpat Wschodnich i życia karpackich górali bardzo przyczyniły się listy, które pisał w roku 1847, w czasie pobytu w Pasiecznej, małej huculskiej wiosce, ukazując w nich piękno

31 Tamże, wiersz pt. Echo, s. 170.

32 W. Bełza, Wincenty Pol. Wspomnienie w 40 rocznicę zgonu poety, Kraków 1912, s. 25-26.

${ }_{33}$ Zob. J.A. Choroszy, Huculszczyzna w literaturze polskiej, Wrocław 1991, s. 92-99.

${ }^{34}$ A. Zieliński, Karola Bołoz Antoniewicza wędrówki śląskie, „Dolny Śląsk” 1999, nr 7, s. 138. 
krainy znad Czeremoszu, ale i skrajną nędzę mieszkańców tej ziemi ${ }^{35}$. Znany jest wiersz Huculska ptaszyna, a także mocno związane z ludowymi pierwowzorami ballady, m.in. Dobosz. Pieśń huculska gór karpackich z okolicy Mikuliczyna.

Jedna z najważniejszych wypraw Pola w Tatry i Pieniny miała miejsce w 1852 roku. Pewnego dnia w Dolinie Kościeliskiej natrafiono na mogiłę, w której pochowany miał być, zabity przez zbójców, młynarz wypłukujący złoto dla króla Zygmunta Starego. Nad mogiłą poeta wygłosił przemowę, kończąc ją poleceniem, by na pamiątkę tych, co polskim królom wiernie służyli, wtoczyć kamień i postawić drewniany krzyż z inskrypcją: „I nic nad Boga”, nawiązującą do słów z listu św. Pawła (por. Rz, 8, 37-39). Odśpiewano też pieśń Kto się w opiekę odda Panu swemu oraz pieśni powstańcze ${ }^{36}$.

Krzyż był częstym elementem romantycznego krajobrazu i nieodłącznym znakiem wiary zarówo u Pola, jak i u Antoniewicza, którego nazywano nawet „polskim Janem od Krzyża”. W wierszu pt. Do łanów Pol malując słowem najpiękniejsze polskie pejzaże, nie zapomina o krzyżach na rozstajach dróg, wskazujących wędrowcom drogę:

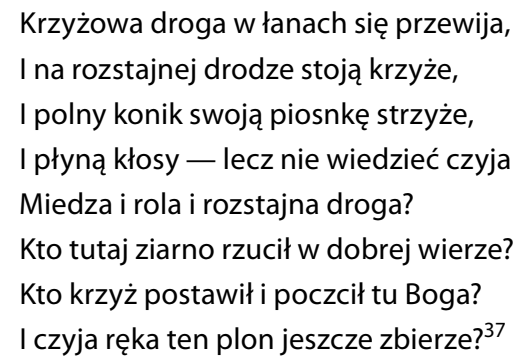

Krzyże stojące na rozstaju dróg lub wieńczące samotne groby są też częstym motywem w młodzieńczej poezji Antoniewicza. „Widząc znak krzyża pielgrzym zboczy z drogi/ I z łzawym okiem przyklęknie na grobie” - wyznaje w wierszu pt. Grobowiec w puszczy. Samotny wędrowiec w tym krzyżu znajdzie oparcie i wskaże na istotną cechę znaku - dominację nad motywem grobu, który w lirykach poety oznacza nowe życie. Później, w poezji kapłańskiej, ten nieodłączny element krajobrazu jako znak zbawienia, wartość życia i droga wskazująca niebo, zyska głęboko duchowy sens, charakterystyczny także dla poezji Wincentego Pola.

\footnotetext{
35 Por. List ks. K. Antoniewicza do ks. T. Baczyńskiego, Pasieczna, czerwiec 1847, w: K. Antoniewicz, Listy z zakonu, list V, Poznań 1849, s. 12.

36 Por. M. Łoboz, Piękna nasza Polska cała... Krajobrazy Wincentego Pola, s. 129.

37 W. Pol, z cyklu Po burzy, w: Dzieła poetyckie Wincentego Pola, t. III, s. 51.
} 


\section{Wspólnota wiary i krzyża}

Wiary autora Pieśni Janusza nie zachwiało nawet ciężkie kalectwo związane z utratą wzroku. Nie stracił nadziei, nie upadł na duchu, lecz korzystając z pomocy innych, tworzył dalej ${ }^{38}$. Gdy Władysław Bełza wyraził mu swe współczucie, odparł pogodnie: „Bóg rozpalił w mojej duszy światło, co nigdy nie gaśnie, a dopóki ono płonie, widzę oczyma duszy jaśniej niż wy fizycznie widzicie. Otworzy Bóg i moje oczy na światło wiekuiste, gdy moja chwila się spełni" ${ }^{39}$. Do księżnej Jadwigi Sapieżyny zaś pisał, że „boleść może jest tak istotną częścią życia, jak dzielność, a może nawet istotniejszą, bo boleść przypina skrzydła do duszy, którymi się do nieba dostać można"40.

Dla obu poetów rolę niezwykle ważną w życiu człowieka pełniła Matka Boża. Mało znana inwokacja rozpoczynająca poemat Pola pt. Wit Stwosz, uzasadniająca poświęcenie utworu życiu cudzoziemskiego artysty, skierowana jest wprawdzie nie do Maryi, lecz do ewangelicznej „mądrej panny”, czuwającej z lampą w dłoni, jednak w toku poematu Witowi ukaże się Matka Boża - czysta Panna i w Jej obecności usłyszy on obietnicę, że odtąd jego dusza świecić będzie na chwałę Boga ${ }^{41}$. W mistycznym spotkaniu rzeźbiarza z Maryją, to właśnie Ona światłem zapali duszę artysty, by od tej chwili służył chwale Stwórcy. Chcąc pójść śladem Mądrej Dziewicy, musi jednak prosić o światło, by nie zabłądził w mrokach cierpienia:
Bo kto raz poznał, kto pokochał Ciebie,
W zorzy porannej i w gwieździstym niebie,
Lub w szumie wody u górskiego stoku,
I w starych gajów uroczystym mroku;
Kto Cię raz poznał na morzu i bitwie,
W ucisku duszy i rzewnej modlitwie,
Ten już za Tobą pójdzie z krzyżem wiernie,
I patrząc w niebo przyjmie w siebie ciernie! ${ }^{42}$

Dla Karola Antoniewicza największą zaś chwałą jest być pokornym sługą Maryi. To Matce Bożej stojącej pod krzyżem zawierzał on swój los, gdy zło

${ }^{38}$ P. Czartoryski-Sziler, Wielcy zapomniani. Wincenty Pol - twórca „Mohorta”, „Nasz Dziennik”, http://www.lwow.com.pl/naszdziennik/pol.html.

${ }^{39}$ W. Bełza, Wincenty Pol. Wspomnienie w 40 rocznicę zgonu poety, s. 31.

${ }^{40}$ W. Pol do Jadwigi Sapieżyny, Kraków, 10 lutego 1850, list nr 172, w: Listy z ziemi naszej..., s. 231.

${ }^{41}$ A. Paluchowski, Poezja stanisławowska i romantyzmu, w: Matka Boska w poezji polskiej. Szkice o dziejach motywu, oprac. M. Jasińska, Z. Jastrzębski, T. Kłak, Lublin 1959, s. 95.

${ }^{42}$ W. Pol, Wit Stwosz, w: Dzieła poetyckie Wincentego Pola, t. IV, oprac. J. Sroczyński, M. Wiśniowiecki, Lwów 1904, s. 53. 
chciało go pokonać, a Ona z powrotem kierowała jego wzrok ku niebu, wskazując na Krzyż swego Syna:

Bo pod tym krzyżem cisza święta, wielka,

Głos jeden dzwoni, ale to głos Boski,

Bo pod tym krzyżem Boża Rodzicielka

I krew, co zbawia, łzy, co koją troski.

A kto raz przebył brudne świata morze,

I pod krzyż stanął, lecz stanął w pokorze,

Ten pełnym sercem i zawsze, i wszędzie

Krzyż Twój, o Jezu, błogosławić będzie ${ }^{43}$.

W poemacie Słowo a sława... Pieśń na pierwsze wiece Słowian, obwołane do Pragi czeskiej na wiosnę roku Pańskiego 1818, Pol pisał, że głębia słowa Bożego zostaje zrozumiana dopiero wówczas, gdy człowiek doświadczony jest przez cierpienie i niewolę:

\author{
Bóg nas - o Bracia - otoczy chwałą, \\ Bo i dziś cóż nas przybliża? \\ Że nam na ziemi nic nie zostało, \\ Prócz pieśni, pługa i krzyża! \\ Pługiem w posiadłość ziemieśmy wzięli, \\ A krzyż nas Pański zwyciężył, \\ I Słowo Boże myśmy pojęli, \\ Kiedy nas obcy ciemiężył! ${ }^{44}$
}

Tylko ten zdoła dźwigać krzyż, kto w życiu kieruje się prawdziwą miłością. Wówczas największy ciężar stanie się światłem w drodze do wieczności. Kiedy rzeźbiarz z poematu Pola podziwiał piękno Maryi, Ona podała mu do ręki krzyż. Gdy zapytał, co ma uczynić z tym trudnym darem, otrzymał odpowiedź:
Krzyż ci spuścizną będzie na tym świecie,
I tylko wówczas zdołasz go podźwignąć,
Jeśli w miłości nie będziesz tu stygnąć,
I za tym jasnym i czystym płomieniem
Przejdziesz po ziemi duchem i sumieniem $!^{45}$

\footnotetext{
${ }^{43}$ K. Antoniewicz, Pieśń 12, w: Poezje religijne, t. 1, wyd. J. Badeni TJ, Kraków 1895, s. 51.

${ }^{44}$ W. Pol, Słowo a sława. Pieśń na pierwsze wiece Słowian, obwołane do Pragi czeskiej na wiosnę roku Pańskiego 1818, w: Dzieła poetyckie Wincentego Pola, t. II, oprac. J. Sroczyński, Lwów 1921, s. 14.

${ }^{45}$ W. Pol, Wit Stwosz, s. 16.
} 
Podobne zadania wyznacza Maryja Karolowi w wierszu pt. W kaplicy Matki Boskiej Bolesnej w Staniątkach. Misjonarz ma z krzyżem w ręku i w sercu z Bogiem przypominać ludziom o wierze, miłości, o historycznych korzeniach Polski i o jej o cierpieniu. Warunkiem zbawienia, które musi dokonać się przez krzyż, jest wiara, miłość i pamięć o chlubnych kartach z dziejów ojczyzny.

\author{
I będę krzyża moc i chwałę głosić; \\ Że nie wart szczęścia, kto nie znał cierpienia, \\ Że o to ciągle mamy prosić, \\ Aby nas drogą prowadził zbawienia ${ }^{46}$.
}

Przywołując zaś postaci Polaków, którzy „nie wstydzili się [...] uchylać zwycięskim laurem uwieńczone czoło przed krzyżem zbawienia"47, pisał o przezwyciężeniu nocy cierpienia dzięki mocnej wierze oraz zwycięstwie krzyża na ziemi. Przekonywał, że naród polski wyuczony długim cierpieniem, „nie siłą oręża, lecz ducha” "zapali pochodnię wiary, cnoty i postępu"48 i zostanie wskrzeszony do nowego życia.

\title{
Miłość i cierpienie ojczyzny
}

\section{RABACJA GALICYJSKA - ROK 1846}

Jednym z największych dramatów ojczyzny, które naznaczyły życie obu poetów, są wydarzenia związane z rabacją galicyjską z roku 1846. W lutym tego roku Pol doznał strasznych skutków rzezi chłopskiej w dworze swego przyjaciela Tytusa Trzecieskiego w Polance blisko Krosna, gdzie przebywał razem z rodziną. Kilka obcych gromad chłopów zrabowało wówczas i zniszczyło cały dwór, a jego żonę Kornelię włóczono po ziemi, bito i raniono kosą. Wszystko widziały przerażone dzieci. „Gdyśmy już mocno osłabli - kilka miesięcy później pisał Pol - przywiązano nas do drzew, otoczono wokoło, zadając okrutne męczarnie. W takim położeniu, po kilku godzinach śmiertelnej trwogi, prosiłem już tylko o śmierć"49.

Odstawiono następnie obydwóch skrwawionych i zbitych dziedziców do starostwa w Jaśle, skąd przewieziono ich, jak przestępców, do więzienia lwowskiego. Tu poeta $\mathrm{z}$ wilgoci, zaduchu i głodu zaczął ciężko chorować. Listy i wiersze

\footnotetext{
${ }^{46}$ K. Antoniewicz, W kaplicy Matki Bolesnej w Staniątkach, w: tenże, Poezje religijne, s. 74.

${ }^{47}$ K. Antoniewicz, Królowa Korony Polskiej, w: Kazania ks. Karola Antoniewicza TJ, wyd. III, zebrał J. Badeni, t. II - Kazania o Matce Bożej, Kraków 1906, s. 11.

${ }^{48}$ Tamże.

49 W. Pol, Pamiętniki, s. 329.
} 
pisane w tym czasie nacechowane są bezbrzeżnym smutkiem ${ }^{50}$. W pożarze dworu utracił wszystkie rękopisy, notatki i rysunki - rezultat dziewięcioletnich studiów i trwającej pięć lat podróży naukowej ${ }^{51}$. Wiele upłynie lat, zanim uda mu się odtworzyć to, co zebrał w czasie licznych wypraw naukowo-badawczych.

Chory i udręczony lękiem o los swej rodziny W. Pol dotknął wówczas piekła głębi duchowego i fizycznego cierpienia. Wtedy też powstały jego wiersze pt. $Z$ więzienia i Siedem psalmów pokutnych $w$ duchu Dawidowym. Gdy uwolniono go po kilku miesiącach, znalazł się bez środków do życia. „Na wpół żywy, z połamanymi żebrami, rok niemal cały przemęczył się nasz ulubiony pieśniarz między życiem a śmiercią, zanim powstał nareszcie z łoża boleści" ${ }^{22}$ - pisał o nim w swych Pamiętnikach Zygmunt Feliński. Dramatyczne przeżycia nie złamały jednak wiary Pola, lecz jeszcze bardziej ją umocniły. Szczerze przywiązany do Kościoła, należał do tych patriotów, którzy uważali katolicyzm za jedyną drogę do nieba i za główną dźwignię zdolną wydobyć naród z moralnego i politycznego upadku ${ }^{53}$. Przyjaciela Wojciecha Stattlera poeta wówczas zapewniał: „Zapytasz mnie zapewne, co się dziś we mnie dzieje. Więc donoszę Ci, żem nie utracił ani miłości, ani nadziei, ani wiary. Bogiem stoję lepiej, niżeli przedtem stałem, więc sądzę, że i do świata trafię i do obowiązków powrócę" ${ }^{\text {"s }}$.

Przewodnie nakazy dotyczące przyszłości, osobisty modus vivendi poety, którym będzie się kierował i skłaniał do tego innych, utrwalił w powstałym wtedy wierszu pt. Godło życia ${ }^{55}$ :

\footnotetext{
Wiernie stanąć na przeszłości,

Jak krew ze krwi, jak kość z kości,

I sumiennie poczcić dzieje,

A w świat przyszły siać miłości,

Ziarna wiary i nadzieje.

Ziemię z niebem związać społem,

Serce z Bogiem, myśl z Narodem,

Słowem, wzorem iść mu przodem

I przymierza opleść kołem.

Nie pobluźnić, nie podwoić,

Lecz miłością bole koić,
}

\footnotetext{
${ }^{50}$ J. Sroczyński, M. Wiśniowiecki (oprac.), przedm. do: Dzieła Wincentego Pola, t. I, Stanisławów 1903, s. 35.

${ }^{51}$ W. Pol, Pamiętniki, s. 330.

52 Z. Sz. Feliński, Pamiętniki, oprac. i przedm. E. Kozłowski, Warszawa 2009, s. 207.

${ }^{53}$ Tamże, s. 201-208.

${ }^{54}$ Cyt. za: M. Mann, Wincenty Pol - studium biograficzno-krytyczne, t. 2, list z 21 lipca 1846, Kraków 1906, s. 31.

${ }^{55}$ Tamże, s. 28.
} 


\section{Pracą ducha uszlachetnić \\ I uwiecznić i uświetnić ${ }^{56}$.}

Tym poetyckim credo zainaugurował Pol wykłady z geografii na Uniwersytecie Jagiellońskim 10 stycznia 1850 roku $^{57}$. Stawszy się jednym z przybranych synów przeszłości, temu przesłaniu pozostanie zawsze wierny, a przewodnikiem na drogach życia będzie dla niego Kościół i dzieje ojczyzny ${ }^{58}$.

Podobny stosunek do wiary, tradycji i przeszłości miał Karol Antoniewicz, który też kierował się myślą, że Bogu trzeba oddać serce, a myśli i troskę poświęcić narodowi i stać się dla niego wzorem postępowania. Przekonywał, że gdy Polska wróci do wiary i do przestrzegania cnót, wówczas nie pokona jej żadna wroga siła. Wierzył, że z wiarą ojców powróci chwała ojczyzny, jej wielkość i wolność. Jest świadomy, że to zadanie nie jest łatwe, więc musi być przygotowany na różne przeciwności:

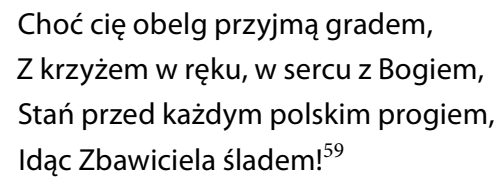

To właśnie on był jednym z najsłynniejszych misjonarzy, którzy z narażeniem życia w 1846 roku prowadzili misje na terenach porabacyjnych. O tym wspomina też Wincenty Pol w liście do ks. Aleksego Prusinowskiego: „Czyż nie ksiądz Karol Antoniewicz nawracał misjami swoimi lud zbuntowany po rzezi 1846 roku?"60. Jego Wspomnienia misyjne stanowią niezwykle ważny dokument - bolesną kronikę tragedii, jaka dotknęła Polaków na terenach podgórskich. $\mathrm{Na}$ podstawie wiarygodnych świadectw ofiar i uczestników rabacji, kapłan skreślił przerażający obraz powstania chłopskiego, zwracając uwagę nie tylko na jego antypański, ale i antykościelny charakter ${ }^{61}$.

\footnotetext{
${ }^{56}$ W. Pol, Godło życia, w: J. Sroczyński, M. Wiśniowiecki, oprac. Dzieła Wincentego Pola, t. I, Stanisławów 1904, s. 335.

${ }^{57}$ Z. Sudolski, Wstęp, w: Z. Krasiński, Listy do Koźmianów, oprac. i wstęp Z. Sudolski, Warszawa 1977, s. 6.

${ }_{58}$ M. Mann, Wincenty Pol - studium biograficzno-krytyczne, t. 1, s. 33-34.

${ }^{59}$ K. Antoniewicz, W kaplicy Matki Boskiej Bolesnej w Staniątkach, s. 72.

${ }^{60}$ Zob. W. Pol do ks. Aleksego Prusinowskiego, list nr 338, w: Listy z ziemi naszej..., s. 376.

${ }^{61}$ Zob. F. Ziejka, Misjonarz wśród rabantów, w: Rok 1846 w Galicji. Ludzie, wydarzenia, tradycje, red. M. Śliwa, Kraków 1997, s. 65-76.
} 


\title{
POŻAR KRAKOWA - ROK 1850
}

Kolejnym dramatem, który bardzo dotknął ojczyznę i obu poetów był dramatyczny w skutkach pożar Krakowa w 1850 roku. Pol bardzo kochał to miasto pełne wspomnień i pamiątek, odwiecznych gmachów i kościołów. Zawsze powracał tutaj z radością. Już w roku 1834 wyśpiewał piękną Pieśń o Krakusowym grodzie, a roku 1844 pisał do Edmunda Krasickiego:

\begin{abstract}
Powiem Ci, że bardzo miłe, szczęśliwe i potrzebne dla serca wyniosłem wrażenia z Krakowa, i dziś nie sowy lęgną się w starym orlym gnieździe! Będąc parę razy na uroczystym nabożeństwie w katedrze krakowskiej, pomyślałem sobie - iż słusznie nazwano ten stary Kraków w Rzymie: urbs ortodoxa, altera Roma! ${ }^{62}$
\end{abstract}

Odkąd tam zamieszkał, miasto stało się mu jeszcze bliższe. Objęcie katedry geografii na Uniwersytecie Jagiellońskim, gdy po dwudziestu latach znów mógł przemówić do polskiej młodzieży, było dla niego ogromną radością, o czym wspominał m.in. w liście do księżnej Jadwigi Sapieżyny:

Uważam to tak właśnie sobie, jak gdyby mi Bóg mowę przywrócił, a zwłaszcza gdy mi ponownie padło przemawiać z katedry, z których niegdyś Święci Pańscy przemawiali do narodu i w czasach tak wielkiego zgorszenia, gdzie głos prawdy nie ma przystępu do serc ludzkich i gdzie prawie już w to tylko uwierzyć należy, że chyba przyczyna tych Świętych Patronów Polskich wyjedna nam łaskę nieba ${ }^{63}$.

Również dla Antoniewicza ten „mały, ukryty Kraków, który jako nieustający Westalek ogień zachowuje, żywi, podnieca w łonie swoim ten święty ogień miłości i narodu" ${ }^{\prime 4}$, był miastem szczególnie drogim. Pierwszy opisowo-liryczny poemat ukazujący piękno królewskiego grodu pt. Bielany, powstał już w 1828 roku. W czasie podróży poeta podziwiał piękno nadwiślańskiej przyrody i pielgrzymował do znajdującego się na wzniesieniu klasztoru Kamedułów. Później już jako kapłan bywał w Krakowie często, a modląc się przy grobach świętych polskich o lepszą przyszłość dla Polski, wszędzie głosił kazania ${ }^{65}$. Jego listy pisane w duchu miłości ojczyzny, zebrane pod wspólnym tytułem pt. Groby świętych polskich, stanowią perłę literatury hagiograficznej romantyzmu.

$\mathrm{Na}$ wieść o pożarze trawiącym ukochane miasto, ks. Karol przybył do Krakowa natychmiast i stał się wówczas dla jego mieszkańców prawdziwym

${ }_{62}$ Zob. M. Mann, Wincenty Pol - studium biograficzno-krytyczne, t. II, s. 119.

${ }^{63}$ Zob. W. Pol do Jadwigi Sapieżyny, list nr 172, w: Listy z ziemi naszej..., s. 231.

${ }^{64}$ K. Antoniewicz, Groby świętych polskich, z. 1, Nowe Piekary 1849, s. 8-9.

${ }^{65}$ J. Koźmian, O kazaniach i pismach ks. Karola Antoniewicza, w: „Przegląd Poznański” 1849, t. 8 , s. 516 . 
aniołem pociechy ${ }^{66}$. Podjął też wtedy ostateczną decyzję, że nigdy nie opuści ojczyzny: „Nie! ja Polski nie porzucę - nie mogę, bo siła Boska mnie tu trzyma [...]. Ten pożar jakby miecz płomienny archanioła stanął i zamknął mi drogę" ${ }^{107}$.

Przez dziesięć dni „nie było ani jednej nocy, która by nie była oświecona łuną pożarów, ani jednego prawie dnia nieprzerwanego alarmem"68. Feliks Koneczny pisał, że był to zamach zaborców na skarbnicę pamiątek narodowych, na biblioteki, zbiory naukowe i świątynie. Cały tydzień gaszono ogień, ale „niewiadomi" podpalacze ponawiali, i to zawsze w kilku różnych stronach miasta, kolejne próby ${ }^{69} .19$ lipca 1850 roku korespondent krakowskiego dziennika „Czas” donosił, że dla miasta wybiła ostateczna godzina ${ }^{70}$.

Skutki pożaru były przerażające. W ciągu trzech dni zniszczył on ponad 160 domów, m.in. pałace i bogate kamienice w Rynku (także Pałac Biskupi i Pałac Wielopolskich), cztery świątynie: św. Franciszka z Asyżu, Świętej Trójcy, św. Norberta i św. Józefa oraz przylegające do nich klasztory Dominikanów, Franciszkanów i sióstr Bernardynek. W tydzień po ugaszeniu pożaru ks. Karol zaczął głosić kazania do przygnębionych klęską krakowian ${ }^{71}$ i na gruzach spalonych świątyń budził uczucie narodowego bólu i miłości do ojczyzny. Zbierane wówczas fundusze dawały nadzieję na ich szybką odbudowę ${ }^{72}$.

Słowa Antoniewicza wywarły wielkie wrażenie na słuchaczy, wśród których był zapewne także Wincenty Pol. Świadczy o tym choćby jego list do ks. Aleksego Prusinowskiego, w którym nawiązując do kazań ks. Karola, pyta: „Czyż nie od jego słowa w końcu wstąpiła nadzieja w podupadłe serca i zaczęły się odbudowywać na nowo kościoły krakowskie?"73. Jeszcze kilkanaście lat później Pol, w liście do ks. Issaka Isakowicza, wspominał „pamiętne i wieszcze” słowa kaznodziei wygłoszone na gruzach Krakowa: „Nie ręce, ale serca budują kościoły"74. Antoniewicz zaś w jednym z listów do księżnej Jadwigi Sapieżyny przyznawał, że jego kazania były „grzmiące i długie”, a kościół Mariacki nie mógł pomieścić słuchaczy. Wspominał też, że po bardzo pracowitym dniu odwiedził

66 Zob. ATJKr, rkps 1012 - I, Pisma i notatki ks. Iwona Czeżowskiego o życiu ks. Karola Antoniewicza..., karta 273.

67 Tamże, z listu K. Antoniewicza, karta 274.

68 Cyt. za: J. Badeni, Ksiądz Karol Antoniewicz, s. 257.

${ }^{69}$ F. Koneczny, Z dymem pożarów, w: tenże, Święci $w$ dziejach Narodu Polskiego, Miejsce Piastowe 1937 - 1939, s. 573-574.

70 Por. J. Badeni, Ksiądz Karol Antoniewicz, s. 257.

71 F. Ziejka, Karol Bołoz Antoniewicz, Kapłan - Misjonarz - Poeta, „Horyzonty Wychowania”, 5(2006), s. 27.

72 Zob. J. Badeni, Ksiądz Karol Antoniewicz, s. 264-271.

73 Zob. W. Pol do ks. Aleksego Prusinowskiego, list nr 338, w: Listy z ziemi naszej..., s. 377.

74 Tamże, W. Pol do ks. Issaka Isakowicza, Kraków, 17 listopada 1868, list nr 441, s. 460. 
Piotra Moszyńskiego i Pola ${ }^{75}$. Już wcześniej liczył też na jego pomoc w sprawie wydania drukiem słynnej homilii wygłoszonej we Lwowie i o pośredniczenie w tej sprawie prosił księżną Jadwigę:

\begin{abstract}
Kościół był napełniony i słowa, co Bóg włożył w usta moje, uderzały w serca. Wszyscy byli zadowoleni. /.../ Po kazaniu P. Stadnicki z Polski, któregom wcześniej nie znał, był u mnie i prosił na wszystko, co mógł, abym mu to kazanie dał, aby on je do Polski zawiózł. Tu także wszyscy urugują, aby je wydrukować. Nie chcę tego czynić dla różnych przyczyn, ale posyłam je nie całe tobie... Rozmów się z Panem Polem, czy by nie można, jeśli sądzi, że może być jaki z tego pożytek, umieścić je jako Wstęp kazania ze Lwowa nadesłany, w dodatku lub felietonie do "Czasu"76.
\end{abstract}

W krakowskim towarzystwie naukowym został wówczas ustanowiony komitet poświęcony sztukom pięknym i archeologii, na początku roku 1850 składający się z trzech tylko członków: prof. Józefa Muczkowskiego, dyrektora biblioteki UJ, Karola Kremera i Wincentego Pola. Rok później komitet został zamieniony w oddział stały, gdyż trzeba było ratować pomniki przeszłości po pożarze Krakowa i restaurować świątynie 77 . Wiele cennych zabytków zostało zniszczonych, nie pozostawiwszy po sobie żadnych zapisów ikonograficznych utrwalających ich wygląd. Pol był wówczas jedną z najważniejszych osób, które tworzyły dokumentację oraz opisy z rysunkami i inskrypcjami rozsypujących się pomników nagrobnych ze spalonych kościołów. Przeszukiwał też ruiny świątyń w celu odnalezienia części odnawianych zabytków i angażował się $\mathrm{w}$ restaurację pogorzałych obiektów ${ }^{78}$.

Kilkanaście lat później, 18 marca 1868 roku, nawiązując do dramatu Krakowa oraz do roli słów ks. Karola przypomniał, w czasie prelekcji w sali krakowskiego towarzystwa naukowego, na temat potrzeby zachowania pomników z przeszłości i ich znaczenia w świecie współczesnym, że:

${ }^{75}$ ATJKr, rkps 932 - A, t. III, Kopie listów ks. Karola Antoniewicza TJ, list z Krakowa, 5 sierpnia 1850, karta 113b; poeci znali się osobiście już wcześniej, być może już od czasów studenckich. Antoniewicz odwiedzał poetę we Lwowie; zob. K. Antoniewicz, Wspomnienie życia zakonnego matki, w: Sylwetki matek kapłanów, red. Z. Walkiewicz, przypis, s. 9.

${ }^{76}$ ATJKr, rkps 932 - A, t. III, Kopie listów ks. Karola Antoniewicza TJ, list ze Lwowa, 9 maja 1850, karta 75b.

${ }_{77}$ W. Pol, O potrzebie zachowania pomników z przeszłości i znaczenie ich w czasie dzisiejszym. Prelekcja miana dnia 18 marca 1868 r. w Sali Towarzystwa Naukowego Krakowskiego przez Wincentego Pola, Kraków 1868, s. 16-17.

${ }^{78}$ U. Bęczkowska, Wincenty Pol a początki instytucjonalnej opieki nad zabytkami sztuki w Polsce, w: Wincenty Pol (1807-1872) w służbie nauki i narodu, red. K. Grodzińska, A. Kotarba, Kraków 2010, s. 81-82. 
Pamiętna zostanie dla Krakowa chwila poświęcenia ankrów przy kościele księży Dominikanów, bo od niej i od słów ks. Karola Antoniewicza, że "nie ręce lecz serca budują kościoły”, poczęły się z gruzów dźwigać te bazyliki w czasach największych niepowodzeń kraju, tak iż podźwignięcie się tych kościołów z ruiny można ludziom małej wiary przytoczyć za przykład, że nie ręce, lecz serca budują kościoły ${ }^{79}$.

W liście do ks. Izaaka Isakowicza z 1886 roku jeszcze raz przypomina te słowa, dodając: „Ks. Karol przed Bogiem, a kościoły krakowskie okazalsze jeszcze niż były, dźwignęły się od węgła i jest chwała Panu, a pokój ludziom dobrej woli. Jest świadectwo, które Pan sam sobie dał mimo upadku i nędzy narodu"80. Podkreśla ten fakt wielkiej odbudowy świątyń i zabytków w dziejach narodu polskiego, „abyśmy - jak pisał - stąd sami brali dla siebie otuchę, że wszystko jest do zrobienia, jeżeli ci, co przewód rzeczy dają, odwołają się do wielkich miłości i wielkich tradycji narodu" ${ }^{\prime 1}$.

\section{Wspólnota tworzenia}

Wincenty Pol był przekonany, że jedynie człowiek naznaczony chrześcijańską charyzmą może wskazać i poprowadzić ludzi ku wolności. Takim przewodnikiem przygotowującym się do swej twórczej pracy przez modlitwę, post i sakramenty, był dla niego m.in. Wit Stwosz ${ }^{82}$. W obszernym poemacie ukazał poeta głębokie przeżycia mistrza, który na początku Wielkiego Postu podjął się dzieła, jakim było wykucie krzyża. Nie mógł go jednak ukończyć. Zraszał swe dzieło łzami i wciąż od niego odstępował. Mękę Jezusa przeżywał tak, jak gdyby wszystko sam widział i sam wszystkiego doświadczał:

\footnotetext{
Gdy przyszło dłutem wznowić Pańską mękę,

I przebić stopy, i przebić mu rękę,

I wcisnąć z ciernia koronę na głowę:

Tom utrapienia cierpiał Judaszowe!

Ale gdy przyszło Panu bok otworzyć,

Na to już w końcu nie stało odwagi,

I grzeszne dłuto musiałem odłożyć:
}

\footnotetext{
${ }^{79}$ W. Pol, O potrzebie zachowania pomników z przeszłości i znaczenie ich w czasie dzisiejszym, s. 17.

${ }^{80}$ W. Pol do ks. Izaaka Isakowicza, Kraków, 17 listopada 1868, list nr 441, w: Listy z ziemi naszej..., s. 460.

${ }^{81}$ W. Pol, O potrzebie zachowania pomników z przeszłości i znaczenie ich w czasie dzisiejszym, s. 18.

${ }^{82}$ Z. Chojnowski, Osobowość religijna Wincentego Pola, w: „Ponad hafem wicher wieje”... Studia o Wincentym Polu, red. N. Kasparek, A. Korytko, Olsztyn 2011, s. 128.
} 
Bo Pan przede mną stanął w prawdzie nagiej,

A bez obrony jako na Golgocie ${ }^{83}$.

Pragnienie życia zgodnego z Bożą wolą stało się podstawowym wyznacznikiem religijnej osobowości Pola. Sztuka i literatura były dla niego przede wszystkim uwidocznieniem w dziele arystycznym Bożego słowa ${ }^{84}$. Dlatego przestrzegał, by świat nie niszczył tego, co w artyście jest święte i przypominał, że kto posiada dar tworzenia, zawsze powinien pamiętać, że pochodzi on od Boga:

\author{
I biada światu! Gdy w złości niweczy \\ To, co w geniuszu po Panu jest święte; \\ A geniuszowi biada! Jeśli przeczy \\ Temu, co dane i od Boga wzięte! ${ }^{85}$
}

Próby literackie inspirowane dziełami Mickiewicza oraz Goethego, Schillera, Byrona, zarówno on, jak i Antoniewicz podjęli już w okresie młodzieńczym. „Począłem pisać pieśni z powodu Adama Mickiewicza" " ${ }^{6}$, zanotował w Pamiętniku Pol, znając na pamięć prawie cały pierwszy tomik ballad i romansów swojego mistrza $^{87}$. Na Karola zaś duży wpływ miały Sonety krymskie ${ }^{88}$. Pierwszy wydany zbiór jego poezji składał się z 23 pisanych po polsku Sonetó ${ }^{89}$, które ukazały się drukiem we Lwowie w 1828 roku.

Obaj twórcy najczęściej publikowali swe utwory w Krakowie i we Lwowie. W kwartalniku „Dzwonek. Pismo młodemu wiekowi poświęcone” z roku 185051 (t. I-IV) ${ }^{90}$ Pol zamieścił prozą m.in. Myśli ulotne i refleksje, Muzykę religijna oraz wiersze: Smutek i wesele, Kropla rosy niebieskiej, czy Nie fraszki, lecz ptaszki. Znajdują się tam też utwory Antoniewicza, m.in. Wspomnienie życia zakonnego, Huculska ptaszyna, O powołaniu kobiety i wiele innych.

Poezja Pola i Antoniewicza miała taki sam cel: służyła „ku pokrzepieniu serc". Obaj poeci często odwoływali się także do tradycji modlitewnej, a w nocy cierpienia, dzięki swej głębokiej wierze w Bożą Opatrzność, zachowali godność i pogodę ducha. Lucjan Siemieński pisał o Polu, że:

83 W. Pol, Wit Stwosz, s. 17.

${ }_{84}$ Z. Chojnowski, Osobowość religijna Wincentego Pola, s. 128.

85 W. Pol, Wit Stwosz, s. 52.

86 W. Pol, Pamiętniki, s. 23.

${ }^{87}$ M. Mann, Wincenty Pol - studium biograficzno-krytyczne, t. 1, s. 50.

${ }_{88}$ W. Bruchnalski, Sonety Mickiewicza w literaturze galicyjskiej w 1827-1828, „Pamiętnik Towarzystwa Literackiego im. Adama Mickiewicza”, Lwów 1898, r. VI, s. 188.

89 K. Antoniewicz, Sonety, z. 1, Lwów 1828.

90 Redaktorem kwartalnika była Walentyna Trojanowska, uczennica ks. Stanisława Jachowicza, a całe wydanie finansowała księżna Jadwiga Sapieżyna. 
Wszędzie znalazł dla siebie echo, czy to w pańskim dworze, czy w zaściankowym dworku, czy za warsztatem, czy pod słomianą strzechą; i to nie w jednej okolicy, [...] wszędzie, gdzie mówiono i modlono się po polsku, gdzie uczucie narodowe wołało o kroplę rosy, żeby nie zwiędnąć w wielkich tęsknotach. Pieśni te były rosą, tym balsamem, podobne do ściśnięcia ręki przyjaznej, wtenczas kiedy się widzimy opuszczonymi i bez żadnej pociechy ${ }^{91}$.

Pieśni do jego słów krążyły przez pokolenia w oderwaniu od swego autora. Przepisywano je, uczono się ich na pamięć, tworzono do nich muzykę. I tak poniekąd spełniły się słowa usłyszane od Mickiewicza, który zapoznawszy się $\mathrm{z}$ pisanymi przez Pola lirykami, z uznaniem przekazał mu swe rady, według których sam tworzył:

Bądź wiernym synem Kościoła, pamiętaj, że religia jest najwyższym uczuciem w naszym narodzie i punktem skupienia. Nie zostawaj na samym pobojowisku, zejdź do chat, a czym niżej zejdziesz, tym więcej znajdziesz. Szukaj tradycji i staraj się mówić językiem, którym zacząłeś mówić, nie jest to nasz język naukowy, ale ty trafiłeś na drogę. Zresztą nie radź się nikogo i nim co napiszesz, nie mów o tym z nikim. Puść twoje poezje bezimiennie w świat; jeżeli się rozszerzą i do ciebie powrócą, możesz być pewnym powodzenia ${ }^{92}$.

W sposób bardzo prosty, przystępny dla każdego, pisał także Karol Antoniewicz, którego pieśni śpiewano w wielu polskich domach, a drukowane niewielkie książeczki dla ludu zachwycały swą prostotą i mądrością. Któż pamięta, że to właśnie spod jego pióra wyszła najbardziej popularna pieśń maryjna, rozbrzmiewająca przez cały maj, pt. Chwalcie łąki umajone? Jest również autorem pieśni W krzyżu cierpienie, $w$ krzyżu zbawienie, kolędy Do Betejemu pełni radości, pieśni Biedny, kto Ciebie nie znał od powicia; Idźmy, tulmy sie jak dziatki do Serca Maryi Matki; O Maryjo, przyjm w ofierze oraz Matko, nie opuszczaj nas! i wielu innych, znanych do dziś. Jego utwory również najdosłowniej trafiły „pod strzechy", spełniając tym samym marzenia romantyków.

Musiały one wywrzeć także duże wrażenie na Zygmuncie Krasińskim, jeśli pod wpływem lektury przesyłanych mu z ojczyzny „książeczek” ks. Karola, z wielkim żalem pisał po jego śmierci do St. E. Koźmiana: „Wiesz, że nieznanych, gdy odejdą, żałuje się rozumem, a nie sercem. Otóż, ks. Antoniewicza, choć go nie znałem oczyma, żałuję sercem, płaczę za nim.[...] Dzięków ci tysiąc za jego chwil ostatnich opis; ze łzamim go czytał. Niechże on u swojej i naszej Królowej teraz wybłaga opieki i zmiłowania się godzinę"93.

${ }^{91}$ L. Siemieński, Wincenty Pol i jego poetyczne utwory, s. 16.

${ }_{92}$ W. Pol, Pamiętniki, s. 197-198.

${ }_{93}$ Z. Krasiński do St. E. Koźmiana, Drezno, 8 grudnia 1852, list nr 96, w: Z. Krasiński, Listy do Koźmianów, s. 426. 
Trzy główne tematy przewijające się w twórczości Pola to: Bóg, ojczysta ziemia i rodzina - to jego osobista trylogia, świat jego miłości. Kochając ziemię i ludzi, nie potrzebował deptać i rozwalać, jak czynili to nowocześni architekci ruin $^{94}$, pisał L. Siemieński. Tym wartościom pozostał wierny do śmierci. Mało jest pisarzy, którzy by byli tak ze sobą zgodni od początku twórczej pracy aż do końca.

Żywa pamięć o Polu - poecie i człowieku trwała jeszcze niemal sześćdziesiąt lat po jego śmierci, ale bladła stopniowo po odzyskaniu niepodległości. $\mathrm{Na}$ pewien czas wyrugowano jego twórczość nawet z podręczników szkolnych, $\mathrm{z}$ racji światopoglądowych. Dziś rozkwita na nowo.

Wierny wyznawanym wartościom, Bogu i ojczyźnie zawsze był też Karol Antoniewicz. Jego liryki to prawdziwe klejnoty polskiej poezji religijnej, a wszelkie listy i pisma dla ludu stanowią najlepszy „balsam pociechy”. Prawie zupełne pominięcie w programach nauczania jego wartościowej twórczości świadczy o tym, że podzielił on los innych naszych poetów piszących z doświadczenia wiary. Trafnie ujął ten problem Lucjan Siemieński, zwracając uwagę, że często miano poety nadaje się zwykłym „składaczom światowych rymów”, a prawdziwa poezja, której twórcy wzbijają się „w siódme niebo na skrzydłach mistycznej miłości”, ukazując piękno nieogarnionego świata duchowego, pozostaje w cieniu ${ }^{95}$. Jednak i w życiu światowego poety zdarzają się chwile, gdy czuje się on wygnańcem na pustyni i wówczas szuka źródeł prawdy, z których rodzi się „twórczość natchnienia i natchnienie twórczości”96.

\section{Bibliografia:}

Antoniewicz K., Sonety, z. 1, Lwów 1828.

Antoniewicz K., Wspomnienia z wędrówki przez Góry Olbrzymie. Riesengebirge w roku 1837, w: „Rozmaitości", (pismo dodatkowe do "Gazety Lwowskiej”), Lwów 1838, nr: 1, 5, 7, 11, 12, $19,31$. Antoniewicz K., Listy z zakonu, Poznań 1849.

Antoniewicz K., O powołaniu kobiety, list IV, Gräfenberg, wrzesień 1849, k. 24-31, w: Archiwum Prowincji Polski Południowej Towarzystwa Jezusowego w Krakowie; rękopis, dalej: ATJKr, rkps 932 - C, t. I, Różne pisma i druki ks. Karola Antoniewicza.

Antoniewicz K., Kopie listów ks. Karola Antoniewicza TJ, w: ATJKr, rkps 932 - A, t. III.

Antoniewicz K., Wyjątek z pamiętników. Rok 1823, „Dzwonek...”, Lwów 1851, t. IV, s. 28-35.

Antoniewicz K., Wspomnienia życia zakonnego „Dzwonek. Pismo młodemu wiekowi poświęcone”, t. I, Lwów 1850-1851, s. 42-48.

Antoniewicz K., Dwa listy o Zofji Antoniewiczowej, w: „Pokłosie. Zbieranka literacka na rzecz sierot”, Poznań 1862, r. Vl, s. 8-22.

Antoniewicz K., Poezje różne, t. Il, wyd. ks. J. Badeni, Kraków 1895.

\footnotetext{
${ }_{94}$ L. Siemieński, Wincenty Pol i jego poetyczne utwory, s. 29.

${ }_{95}$ Tenże, Święci poeci. Pieśni mistycznej miłości, Lwów 1877, s. 6.

96 Tamże, s. 7-8.
} 
Antoniewicz K., W kaplicy Matki Bolesnej w Staniątkach, w: Poezje religijne, t. I, wyd. J. Badeni, Kraków 1895, s. 64-74.

Antoniewicz K., Królowa Korony Polskiej, w: Kazania ks. Karola Antoniewicza TJ, wyd. III, zebrał ks. J. Badeni, t. II - Kazania o Matce Bożej, Kraków 1906.

Badeni J., Ksiądz Karol Antoniewicz, Kraków 1896.

Barącz S., Antoniewicz de Bołoz Karol, w: tenże, Żywoty sławnych Ormian, Lwów 1856, s. 16-28.

Bełza W., Wincenty Pol. Wspomnienie w 40 rocznicę zgonu poety, Kraków 1912.

Bęczkowska U., Wincenty Pol a początki instytucjonalnej opieki nad zabytkami sztuki w Polsce, w: Wincenty Pol (1807-1872) w służbie nauki i narodu, red. K. Grodzińska, A. Kotarba, Kraków 2010, s. 71-95.

Bruchnalski W., Sonety Mickiewicza w literaturze galicyjskiej w 1827-1828, „Pamiętnik Towarzystwa Literackiego im. Adama Mickiewicza", Lwów 1898, r. VI, s. 184-214.

Chojnowski Z., Osobowość religijna Wincentego Pola, w: "Ponad hafem wicher wieje”... Studia o Wincentym Polu, red. N. Kasparek, A. Korytko, Olsztyn 2011, s. 121-132.

Choroszy J. A., Huculszczyzna w literaturze polskiej, Wrocław 1991, s. 92-99.

Czartoryski-Sziler P., Wielcy zapomniani. Wincenty Pol - twórca "Mohorta" , „Nasz Dziennik", http:// www.lwow.com.pl/naszdziennik/pol.html [25.05.2017].

Czeżowski l., Pisma i notatki ks. Iwona Czeżowskiego o życiu ks. Karola Antoniewicza, które posłużyły ks. Badeniemu za materiał do napisania dzieła "Ksiądz Karol Antoniewicz", w: ATJKr, rkps 1012 - I.

Feliński Z., Pamiętniki, oprac. i przedm. E. Kozłowski, Warszawa 2009.

Koneczny F., Z dymem pożarów, w: tenże, Święci w dziejach Narodu Polskiego, Miejsce Piastowe 1937-1939, s. 556-582.

Koźmian J., O kazaniach i pismach ks. Karola Antoniewicza „Przegląd Poznański” 1849, t. 8, s. 470-516.

Krasiński Z., Listy do Koźmianów, oprac. i wstęp Z. Sudolski, Warszawa 1977.

Łoboz M., Piękna nasza Polska cała... Krajobrazy Wincentego Pola, Wrocław 2007.

Mann M., Wincenty Pol - studium biograficzno-krytyczne, t. 1-2, Kraków 1904-1906.

Morzycka F., Wincenty Pol: życiorys, Warszawa 1899.

Paluchowski A., Poezja stanisławowska i romantyzmu, w: Matka Boska w poezji polskiej. Szkice o dziejach motywu, oprac. M. Jasińska, Z. Jastrzębski, T. Kłak, Lublin 1959, s. 61-114.

Pol W., O potrzebie zachowania pomników z przeszłości i znaczenie ich w czasie dzisiejszym. Prelekcja miana dnia 18 marca 1868 r. w Sali Towarzystwa Naukowego Krakowskiego przez Wincentego Pola, Kraków 1868.

Pol W., Zegar niebieski doroczny, w: tenże, Rok myśliwca (z rysunkami Juliusza Kossaka), Poznań 1870.

Pol W., Wit Stwosz, w: Dzieła poetyckie Wincentego Pola, t. IV, oprac. J. Sroczyński, M. Wiśniowiecki, Lwów 1904.

Pol W., Słowo a sława. Pieśń na pierwsze wiece Słowian, obwołane do Pragi czeskiej na wiosnę roku Pańskiego 1818, w: Dzieła poetyckie Wincentego Pola, t. II, oprac. J. Sroczyński, Lwów 1921.

Pol W., Pamiętniki, oprac. K. Lewicki, Kraków, 1960.

Pol W., Listy z ziemi naszej. Korespondencja Wincentego Pola z lat 1826-1874, wstęp i oprac. Z. Sudolski, Warszawa 2004.

Siemieński L., Wincenty Pol i jego poetyczne utwory, Kraków 1873.

Siemieński L., Święci poeci. Pieśni mistycznej miłości, Lwów 1877.

Wiśniowiecki M., przedm. do: Dzieła poetyckie Wincentego Pola, t. III, Stanisławów 1903, s. 13-17.

Ziejka F., Misjonarz wśród rabantów, w: Rok 1846 w Galicji. Ludzie, wydarzenia, tradycje, red. M. Śliwa, Kraków 1997, s. 65-76.

Ziejka F., Karol Bołoz Antoniewicz, Kapłan - Misjonarz - Poeta „ „Horyzonty Wychowania”, 5 (2006), s. 17-38.

Zieliński A., Karola Bołoz Antoniewicza wędrówki śląskie, „Dolny Śląsk” 1999, nr 7, s. 134-139. 


\section{Streszczenie}

Wincenty Pol i ks. Karol Antoniewicz urodzili się w tym samym - 1807 roku. Pol bardzo cenił ks. Antoniewicza i innych polskich Ormian za ich pracę dla ojczyzny, za to, że wprowadzają polski język, polskie zwyczaje i wiarę katolicką. Podobnie, jak K. Antoniewicz, W. Pol brał udział w powstaniu listopadowym, podobnie też uczestniczył w dramatycznych wydarzeniach związanych z rabacją galicyjską, czy pożarem Krakowa w 1850 roku. Obu poetów łączy umiłowanie ojczystej przyrody, piękno polskiego patriotyzmu i przekonanie, że u źródeł tożsamości narodu leży wspólnota wiary i tradycja języka. Obaj swe pierwsze utwory publikowali we Lwowie. Ich poezja służyła „ku pokrzepieniu serc". Obaj poeci często odwołują się do tradycji modlitewnej. Ich twórczość przeniknięta jest prostotą.

Franciszek Wężyk pisał o W. Polu, że jest to pełen talentu pisarz, który z pięknymi zdolnościami łączy złote serce: „Myśl jego to iskry z niebios, a dźwięk wyrazów - muzyka”. Słowa te doskonale pasują także do osoby ks. Antoniewicza, poety którego również warto przypomnieć. Obaj w głębi nocy cierpienia, dzięki swej głębokiej wierze w Bożą Opatrzność, zachowali godność i pogodę ducha.

słowa klucze: Wincenty Pol, Karol Antoniewicz, wspólnota wiary i tradycja języka.

\section{Wincenty Pol and fr. Karol Antoniewicz - community of spirit and creativity}

\section{Summary}

Wincenty Pol and Fr. Karol Antoniewicz were born in the same - 1807 year. Pol admired Fr. Antoniewicz and other Polish Armenians for their work for the good of the homeland, for introducing the Polish language, Polish customs, and the Catholic faith. Just as Fr. Antoniewicz had, W. Pol participated in the November Uprising, as well as participated in the dramatic events of the Galician Slaughter of 1846 and the Kraków fire in 1850. At that time, they must have met in person, too. Both poets connected the love of their homeland's nature with the beauty of Polish patriotism, and had the conviction that the community of faith and language were sources of the nation's identity. Both published their first writings in Lwów. Their poetry served to invigorate hearts. Both frequently referred to the tradition of prayer. Their activity was suffused by a simplicity.

Franciszek Wężyk wrote that Pol was a talented writer, who combined beautiful abilities with a gold heart: „His thoughts are as sparks from heaven, and the sound of words - music”. These words also fit beautifully to the figure of Fr. Antoniewicz, a poet who is also worth remembering. Both, thanks to their deep faith in God's Providence, retained their dignity and serenity in the deep night of suffering.

keywords: Wincenty Pol, Karol Antoniewicz, faith and language were sources of the nation's identity. 